\title{
MANAJEMEN DISIPLIN KERJA: Perspektif Tenaga Pendidik dan Kependidikan
}

\author{
Muh. Hizbul Muflihin \\ Fakultas Tarbiyah dan Ilmu Keguruan IAIN Purwokerto \\ Jalan Ahmad Yani No. 40-A Purwokerto \\ Email: hizbulmuflihin@ymail.com
}

\begin{abstract}
Abstrak:
Kedisiplinan merupakan fungsi operatif dari manajemen sumber daya manusia yang amat penting, karena semakin baik tingkat kedisiplinan pegawai, maka akan semakin tinggi pula prestasi kerja yang dapat dicapai. Tanpa disiplin yang baik sulit bagi organisasi untuk mewujudkan hasil kerja yang bermutu dan optimal. Disiplin pada dasarnya merupakan tindakan manajemen untuk mendorong agar para anggota organisasi dapat memenuhi berbagai ketentuan dan peraturan yang berlaku dalam suatu organisasi, yang di dalamnya mencakup (1) adanya tata tertib atau ketentuan-ketentuan, (2) adanya kepatuhan para pengikut, dan (3) adanya sanksi bagi pelanggar. Disiplin di dalam lingkungan pendidikan memiliki tujuan yang jelas yaitu munculnya sikap dan prestasi kerja yang baik yang dilandasi kesadaran dan tanggung jawab. Dengan demikian disiplin dipandang berpengaruh secara langsung dan cukup besar terhadap mutu pendidikan. Untuk mendisiplinkan pegawai agar secara riil masuk kerja, pada saat ini masih dipandang efektif dengan menggunakan alat finger print. Namun, penggunaan finger print seringkali memunculkan adanya miskomunikasi karena kesalahan identifikasi input sidik jari dari operator. Dengan begitu, dipandang penting bahwa pendisiplinan pegawai dapat dilakukan dengan cara menanamkan jiwa kejujuran dan sikap amanat dalam menjalankan tugas.
\end{abstract}

\begin{abstract}
Abstrak:
Current life reality has indicated the phenomenon of modern human who have distance from their spiritual awareness. This cannot be separated from the role of parents whose primary task to plant religious values in their family members. Families who are aware of the importance of religious education in the life of their children will definitely create persons with strong spiritual defence towards the challanges of modernity. Conversely, otherwise. Parents is the most influential party in the successfull development of children. However, many parent are currently not aware of their significant role in the personality development of their children. Many parent completely entrust the education of their children to particular school institutions without reliable synergy between the educational institutions and parents for the education of children. As the parenting concept is aimed at preparing strong and high quality generation, it is absolutely important for parents to build their self-capacity with parenting education. This is because in Islamic education, the parenting education is closely linked to pre-conception, pre-natal, and post-natal educations. Therefore, parent candidates must have parenting education in order to generate strong and high quality generations.
\end{abstract}

Kata kunci:

Kedisiplinan, Kehadiran, Ketaatan, Prestasi Kerja, Kejujuran, dan Amanah 
KATA disiplin merupakan satu kata yang penuh dengan konsep performansi seseorang dalam bekerja. Kata disiplin merujuk pada sejenis keterlibatan dan keterikatan seseorang terhadap aturan dalam mencapai standar kerja yang baik, bermutu, dan tepat dengan cara mengikuti peraturan yang telah ditetapkan melalui perwujudan suatu aktivitas. Lalu, aktivitas itu sendiri dapat meliputi hal hal yang sangat khusus, misalnya aktivitas dalam pendidikan saja, tetapi juga dapat meliputi serba aktivitas yaitu semua aktivitas dalam kehidupan. ${ }^{1}$ Untuk menjadikan seseorang berdisiplin dalam bekerja, dibuatlah suatu peraturan dan tata tertib, sehingga kedua hal ini merupakan sesuatu yanmg berfungsi untuk mengatur perilaku yang diharapkan pada diri seseorang.

Peraturan menunjukan adanya patokan atau standar yang sifatnya umum yang harus dipenuhi oleh guru, siswa, dan seluruh pihak sekolah/madrasah, misalnya kehadiran dan kepulangan masuk dan keluar kantor, mengikuti upacara bendera dan rapat-rapat. Sedangkan tata tertib menunjukan patokan atau standar untuk aktivitas khusus, misalnya pakaian seragam. ${ }^{2}$ Dalam konteks keguruan, disiplin mengarah pada kegiatan yang berfungsi mendidik setiap person untuk tunduk dan patuh terhadap aturan-aturan lembaga. Unsur-unsur disiplin terdapat meliputi pedoman perilaku, peraturan yang konsisten, hukuman, dan penghargaan.

Persoalan disiplin kerja (khususnya bagi Aparatur Sipil Negara atau ASN) terus diupayakan perbaikan dan penyempurnaannya. Hal ini dilandasi oleh asumsi bahwa dengan adanya budaya disiplin yang tinggi (biasanya ditandai dengan tingkat ketidakhadiran yang rendah, bahkan jika mungkin zero persen), maka akan meningkatkan kualitas kerja. Kualitas kerja dalam dunia pendidikan ditandai dengan banyaknya layanan yang baik dan tuntas yang telah diberikan kepada konsumen. Jika hal ini dikaitkan dengan proses pembelajaran di Perguruan Tinggi, kedisiplinan yang tinggi oleh Aparatur Sipil Negeri (ASN), ditandai dengan tingkat kuantitas kehadiran dosen dalam mengajar.

Upaya pemerintah untuk menjadikan ASN berbudaya dan berdisiplin tinggi dapat dikatakan sudah dilakukan melalui reformasi. Jika di tahun sebelum 80-an kedisiplinan pegawai negeri cukup ditandai dengan pengisian daftar hadir (tanda tangan) satu kali saja (saat kedatangan), kemudian pada awal tahun 90-an untuk memantau tingkat kedisiplinan pegawai dengan pengisian dan penandatangan daftar hadir sebanyak dua kali (satu kali saat kedatangan dan satu kali saat kepulangan, itupun diminta pula menuliskan pada jam berapa pegawai tersebut datang atau pulang), maka kini di awal tahun 2000-an (abad Teknologi dan Informasi) pemantauan kedisiplinan pegawai dilakukan dengan keharusan pegawai untuk melakukan fingerprint.

Dengan adanya fingerprint ini diharapkan setiap Aparatur Sipil Negara dapat memenuhi tingkat kehadiran yang tinggi (karena terdeteksi secara elektronik dan terkoneksi secara sistemik). Namun, ada satu hal mendasar yang patut untuk dimengerti dan dijawab, apakah dengan pemberlakuan fingerprint seorang pegawai secara otomatis dijamin telah menunjukkan kinerja baik, berkualitas, dan ikhlas? Jika 
tidak demikian adanya, adakah faktor lain yang perlu dipikirkan untuk dirancang dan ditumbuhkan pada setiap aparatur sipil negara khususnya, agar benar-benar hadir secara disiplin (walaupun tidak dengan fingerprint), sehingga terdapat keihklasan dalam bekerja dan melayani konsumen.

\section{BUDAYA DISILIN KERJA}

Disipin kerja dipahami sebagai adanya sikap untuk taat dan patuh pada peraturan. Disiplin juga mengandung arti kepatuhan pada perintah pemimpin, perhatian dan kontrol yang kuat terhadap penggunaan waktu, tanggung jawab atas tugas yang diamanahkan, serta kesungguhan terhadap bidang keahlian yang ditekuni. ${ }^{3}$ Selanjutnya, disiplin adalah sebuah proses yang digunakan untuk menghadapi permasalahan kinerja. Proses ini melibatkan manajer dalam mengidentifikasi dan mengomunikasikan masalah-masalah kinerja kepada para pegawai. ${ }^{4}$ Sedangkan pengertian lain dari disiplin adalah suatu keadaan tertib dimana orang-orang yang tergabung dalam suatu organisasi tunduk pada peraturan-peraturan yang telah ada dengan rasa senang. ${ }^{5}$ Selanjutnya, disiplin adalah ketaatan dan ketepatan pada suatu aturan yang dilakukan secara sadar tanpa adanya dorongan atau paksaan pihak lain atau suatu keadaan dimana sesuatu itu berada dalam tertib, teratur dan semestinya, serta tiada sesuatu pelanggaran baik secara etik maupun moral.

Sikap disiplin adalah kesadaran dan kesediaan seseorang untuk mentaati semua peraturan perusahaan dan norma-norma sosial yang berlaku. Dengan begitu, kesadaran adalah sikap seseorang secara sukarela menaati semua peraturan dan sadar akan tugas dan tanggung jawabnya. Pendapat lainnya mengatakan bahwa kesediaan adalah suatu sikap, tingkah laku, dan perbuatan seseorang sesuai dengan peraturan perusahaan, baik yang tertulis maupun yang tidak. Kedisiplinan dapat diartikan bilamana karyawan selalu datang dan pulang tepat pada waktunya, mengerjakan pekerjaannya dengan baik, mematuhi semua peraturan perusahaan dan norma-norma sosial yang berlaku. ${ }^{6}$

Disiplin di dalam lingkungan pendidikan memiliki tujuan yang jelas yaitu munculnya sikap dan prestasi kerja yang baik yang dilandasi kesadaran dan tanggung jawab. Dengan demikian, disiplin dipandang berpengaruh secara langsung dan cukup besar terhadap mutu pendidikan. Tujuan disiplin yaitu agar kegiatan pendidikan di sekolah/madrasah dapat berlangsung secara efektif dalam suasana tenang, tentram, dan setiap tenaga pendidik beserta tenaga kependidikan di sekolah/ madrasah dapat merasa puas dalam bekerja karena terpenuhi kebutuhannya. ${ }^{7}$ Tujuan disiplin dibagi menjadi dua yaitu tujuan umum dengan maksud agar kurikulum bisa terimplementasikan dengan baik dan efektif, yang menunjang peningkatan mutu pendidikan. Sedangkan tujuan khusus berupa adanya disiplin kerja dengan maksud agar: (a) kepala sekolah/madrasah dapat menciptakan suasana kerja yang menggairahkan bagi seluruh peserta warga sekolah/madrasah, (b) guru dapat melaksanakan proses pembelajaran seoptimal mungkin dengan semua sumber yang ada di sekolah/madrasah dan di luar sekolah/madrasah, (c) tercipta kerja sama yang erat 
antara sekolah/madrasah dengan warga belajar (pendidik, tenaga kependidikan dan para pembelajar).

Masalah disiplin sangat penting dan mendasar untuk dikembangkan di setiap lembaga pendidikan. Sebab, hal ini tidak hanya bermanfaat bagi sekolah/madrasah, melainkan juga amat bermanfaat bagi tenaga pendidik khususnya (sebagai pelaksana pendidikan secara langsung) dan tenaga kependidikan (sebagai penyelenggara pendidikan secara langsung pula). Dengan adanya disiplin kerja guru, kegiatan sekolah/madrasah dan penyelenggaraan pendidikan dapat dilaksanakan dengan tertib dan lancar. ${ }^{8}$ Dengan begitu, dampaknya adalah pembelajaran dapat dilaksanakan dengan tepat waktu sehingga target kurikulum dapat tercapai.

Selain itu, dampak dari disiplin kerja aparatur lembaga pendidikan adalah munculnya prestasi pembelajar yang dapat terwujud secara optimal dan berkualitas. Tidak ada lagi tenaga pendidik terlambat masuk kerja (mengajar) dan tidak ada lagi tenaga pendidik yang mengajar asal-asalan tanpa persiapan dan target yang jelas. Tidak ada lagi tenaga kependidikan yang bekerja sesuai selera hati (tidak ada target karena waktunya tidak cukup). Jelasnya semua pekerjaan sesuai dengan standar waktu dan standar kualitas yang telah ditetapkan sebelumnya. Hal tersebut jelas sangat berpengaruh terhadap munculnya suasana kerja dan kualitas kerja yang terukur. Disiplin kerja yang tinggi dan baik akan dapat menciptakan suasana kerja yang kondusif, penuh dengan gairah untuk meraih prestasi kerja yang sebaik-bakinya.

Dampak yang tidak terlihat langsung adalah munculnya sikap saling menghormati, saling percaya dan saling bersinergi dalam bekerja (karena dipicu oleh munculnya kesadaran keberhasilan bersama). Tidak ada permasalahan dan sikap cemburu, marah, dan jengkel (karena disebabkan oleh kualitas kerja di pihak lain yang berpengaruh terhadap keberhasilan kinerjanya). Suasana kerja yang demikian dapat menciptakan lingkungan kerja yang menyenangkan dan menciptakan semangat kerja. Para guru dapat bekerja dengan senang hati sehingga bersedia mencurahkan segenap tenaga dan pikirannya untuk mencapai visi dan misi sekolah/ madrasah.

Henry Simamora mengemukakan bahwa kegunaan disiplin dalam organisasi dapat diperlihatkan dalam empat perspektif, yaitu:

1. Perspektif retribusi, disiplin kerja berguna untuk menghukum para pelanggar aturan sekolah/madrasah. Pendisiplinan dilakukan secara proporsional dengan sasarannya.

2. Perspektif korektif, disiplin kerja berguna untuk mengoreksi tindakan guru yang tidak tepat. Sanksi yang diberikan bukan sebagai hukuman, melainkan untuk mengoreksi perilaku yang salah. Biasanya guru yang melanggar aturan dipantau apakah ia menunjukan sikap untuk mengubah perilaku atau tidak.

3. Perspektif hak-hak individu, disiplin kerja berguna untuk melindungi hak-hak dasar guru.

4. Perspektif utilitarian, disiplin kerja berguna untuk memastikan bahwa manfaat penegakan disiplin melebihi konsekuensi-konsekuensi negatif yang harus ditang- 
gung sekolah/madrasah.

5. Pentingnya kedisiplinan merupakan fungsi operatif manajemen sumber daya manusia yang terpenting, karena semakin baik disiplin karyawan, semakin tinggi prestasi kerja yang dapat dicapainya. Tanpa disiplin yang baik sulit bagi organisasi mencapai hasil yang optimal. ${ }^{9}$

Menurut Tulus Tu'u, istilah disiplin berasal dari bahasa Inggris dicipline mengandung beberapa arti yang penting di antaranya:

1. Pengendalian diri

Orang yang disiplin adalah orang yang mampu mengendalikan diri, menguasai diri, ataupun membentuk tingkah laku yang sesuai dengan sesuatu yang sudah ditetapkan oleh diri sendiri maupun orang lain.

2. Membentuk karakter yang bermoral

Pembentukan tingkah laku atau karakter yang sesuai dengan yang diharapkan dapat menggunakan kedisiplinan. Dalam artian, orang akan terbiasa melakukan sesuatu yang baik jika ia mendisiplinkan untuk berbuat sesuatu yang baik. Sebaliknya, orang akan sering kali melanggar apabila ia terbiasa melanggar sesuatu.

3. Memperbaiki dengan sanksi

Pada umumnya, orang yang berusaha untuk menjadi diri yang disiplin akan menerapkan sanksi jika melanggar sesuatu yang sudah menjadi komitmen. Adanya sanksi akan membuat seseorang berusaha untuk tetap berada digaris komando kedisiplinan.

4. Kumpulan tata tertib untuk mengatur tingkah laku

Orang yang disiplin dapat dipastikan memiliki sekumpulan tata tertib sebagai pedoman dalam bertindak. Tata tertib ini juga menjadi dasar dari segala sesuatu yang akan dilakukan, baik dari segi ucapan, tingkah laku, tempat dan waktu. ${ }^{10}$

Orang yang berdisiplin akan senantiasa mematuhi peraturan yang telah ditentukan oleh lembaga dan atau apa yang telah disepakati bersama. Setiap tenaga pendidik dan tenaga kependidikan wajib memiliki sikap disiplin dalam melaksanakan tugasnya. Tenaga pendidik yang disiplin senantiasa akan melaksanakan tugas dan tanggung jawabnya sesuai dengan ketentuan yang berlaku. Selain itu tenaga pendidik maupun tenaga kependidikan yang disiplin adalah individu yang berkomitmen terhadap ikrar setia yang diucapkan pada saat pelantikan dan pengambilan sumpah jabatan.

Sebaliknya, tenaga kependidikan dan tenaga pendidik yang bersikap tidak disiplin adalah yang sering melanggar aturan, tidak bertangung jawab atas amanat yang diberikan dan bekerja tanpa memiliki rasa tanggung jawab untuk meraih keberhasilan yang bermutu. Dengan demikian jelaslah bahwa kedisiplinan harus ditegakkan dalam suatu lembaga pendidikan, karena tanpa dukungan disiplin yang baik, maka lembaga pendidikan akan mengalami kesulitan untuk mewujudkan visi dan misinya. Kedisiplinan akan membawa pada ketercapaian tujuan pendidikan dengan hasil yang maksimal. 
Apabila dilihat dari sifatnya, menurut Oteng Sutrisno dalam Barnawi dan Mohammad Arifin, disiplin dapat dibagi menjadi dua yaitu:

1. Disiplin Positif merupakan suatu sikap dan iklim organisasi yang setiap anggotanya mematuhi peraturan-peraturan organisasi atas kemauannya sendiri. Mereka patuh pada tata tertib tersebut karena mereka memahami, meyakini, dan mendukungnya. Selain itu, mereka berbuat begitu karena benar-benar menghendakinya bukan karena takut akan akibat ketidakpatuhannya. Dalam suatu organisasi yang telah menciptakan disiplin positif, si pelanggar ditetapkan memperoleh suatu hukuman. Namun, hukuman yang diberikan bukan untuk melukai atau memecat, melainkan untuk memperbaiki dan membetulkan. Disiplin positif memberikan suatu pandangan bahwa kebebasan mengandung konsekuensi, yakni kebebasan harus sejalan dengan tanggung jawab.

2. Disiplin Negatif di sini adalah suatu keadaan disiplin yang menggunakan hukuman atau ancaman untuk membuat orang-orang mematuhi perintah dan mengikuti peraturan hukuman. Pendekatan disiplin negatif ini adalah menggunakan hukuman pada pelanggaran peraturan untuk menggerakan dan menakutkan guru sehingga mereka tidak akan berbuat kesalahan yang sama. Disiplin negatif cenderung bertumpu kepada konsepsi lama, yaitu sumber disiplin adalah otoritas pimpinan. Hukuman merupakan ancaman bagi guru atau pegawai. ${ }^{11}$

\section{EFEKTIVITAS DAN SPESIFIKASI FINGER PRINT}

Munculnya presensi dengan menggunakan alat atau teknologi tinggi (baca: elektronic) pada dasarnya disebabkan oleh beberapa hal, di antaranya adalah masalah ketidakseimbangan antara upah yang telah dibayarkan oleh seseorang atau lembaga dengan kualitas layanan yang diberikan. Munculnya kualitas kerja atau layanan yang rendah diduga penyebabnya adalah masalah kehadiran pegawai yang kurang atau bahkan kosong (tidak sesuai dengan standar ukuran waktu yang pasti). Akibat tidak adanya standarisasi ukuran waktu berupa lamanya seorang pegawai harus bekerja, maka dipandang sebagai penyebab rendahnya kualitas layanan.

Berangkat dari kenyataan di atas, maka para ahli elektronik atau digital terdorong untuk mencoba membuat alat yang mampu mendeteksi secara baik, apakah seorang pegawai telah benar-benar masuk kerja atau tidak. Hal ini tentu tidak mungkin hanya berpikir dari sisi elektornik saja, tetapi justeru yang harus dipikirkan adalah keberadaan seseorang itu dapat diinput sebagai dasar memutuskan bahwa ia telah masuk kerja atau tidak, atau sudah masuk kerja, tetapi terlambat atau tidak. Di sinilah kemudian muncul apa yang disebut dengan ilmu biometrik, yaitu ilmu untuk mengindentifikasi seseorang berdasarkan karakteristik fisik atau perilakunya. Biometrik kini memang menjadi sebuah trend yang sedang diterapkan pada semua sektor layanan publik (tidak terkecuali lembaga pendidikan tinggi). Aspek pada diri seseorang yang bisa diinput sebagai dasar untuk memonitor bahwa seseorang telah masuk kerja atau tidak, terlambat atau tidak, kini pilihannya sudah sangat beragam, mulai dari sidik jari, pola wajah, pola suara hingga lapisan iris dari mata. 
Dari sekian macam aspek input pada diri seseorang tersebut, aspek sidik jari menjadi hal pertama yang dipakai di setiap lembaga layanan publik. Selain sidik jari, pola wajah juga menjadi pilihan kedua. Dua hal tersebut kini dipandang cukup efektif dan valid untuk memutuskan bahwa seseorang telah masuk kerja atau tidak.

Absen sidik jari adalah suatu metode baru yang saat ini telah berkembang menggunakan mesin dengan bantuan software untuk mengisi data kehadiran suatu komunitas, baik di instansi pemerintah maupun instansi swasta. Mesin absensi sidik jari dan atau pola wajah dirancang khusus dengan teknologi terdepan saat ini. Mesin ini biasanya memiliki kapasitas memori yang besar dan dilengkapi dengan fitur canggih, seperti: USB Flash, Disk, Web Server, Schedule Bell, SMS, Workcode, dan Function Key.

Scanning input dari sidik jari dilakukan dengan menggunakan alat elektronik (mesin absensi sidik jari). Hasil scanning yang didapat lalu disimpan dalam format digital pada saat registrasi atau enrollment atau pendaftaran sidik jari. Setelah itu, rekaman sidik jari tersebut diproses dan dibuatkan daftar pola fitur sidik jari yang unik. Pola fitur sidik jari yang unik tersebut kemudian disimpan dalam memori atau database. Pola sidik jari yang unik ini disebut dengan istilah minutiae. Pada saat identifikasi, pola minutiae tersebut kemudian dicocokkan dengan hasil scan sidik jari. Merujuk pada enrollment, seseorang tidak akan bisa finger print dengan jari yang berbeda dengan jari pada saat awal melakukan pendaftaran. Dengan demikian konsistensi pengggunaan jari saat finger menjadi penting untuk memastikan bahwa seseorang telah dicatat hadir.

Alat absensi sidik jari maupun sensor sidik jari yang digunakan untuk keperluan lain seperti akses kontrol mempunyai beberapa teknik pembacaan sidik jari. Teknik pembacaan sidik jari oleh mesin absensi sidik jari tersebut antara lain: thermal, ultra sonik, kapasitans, dan optis. Di antara macam-macam mesin sidik jari sebagai alat kontrol kedisiplinan pegawai (kehadiran dan atau ketidakhadirannya) dalam teknik ini, pola sidik jari menjadi alat yang dipandang cukup efektif (saat ini) untuk mendongkrak kehadiran pegawai dan sekaligus sebagai alat menekan ketidakdisiplinannya. Alat optis ini bekerja dengan cara merekam sidik jari dengan camera atau discan yang menggunakan cahaya. Kelemahan pada teknik ini bisa diakali dengan jari palsu, walaupun mempunyai keuntungan yaitu mudah dilakukan dan tidak membutuhkan biaya yang mahal.

Penggunaan finger print sebagai alat pengawasan pegawai untuk saat ini dipandang yang cukup baik dan efektif untuk meningkatkan kehadiran dan kualitas kerja pegawai. Hal ini memang tidak salah, karena penggunaan finger print di lembaga pendidikan khususnya dapat memiliki beberapa keuntungan selain juga ada kekurangannya. Di antara keuntungannya adalah menekan dana pengeluaran fiktif karyawan. Dengan penggunaan finger print, jenis dan volume kerja pegawai dapat diukur sejauhmana waktu yang tersedia dapat dimanfaatkan secara maksimal sesuai aturan. Dengan demikian, kualitas kerja pegawai dihitung dengan cara mengukur seberapa banyak tugas dan kewajibannya yang sudah diselesaikan. Jadi, banyak atau 
sedikitnya volume kerja yang telah diselesaikan tidak ada kaitannya dengan besaran gaji yang telah diberikan setiap bulannya. Ini berarti besarnya gaji yang menjadi hak pegawai untuk diterima tidak akan dikurangi dengan kondisi riil kuantitas dan kualitas kerja yang telah dihasilkan. Mengapa demikian? Sebab, konsep penggunaan finger print lebih menekankan pada aspek kehadiran saja. Dengan begitu, bisa saja seseorang yang telah funger print kemudian tidak bekerja dan atau kerja secara santai. Jadi, jelas bahwa pegawai yang mengharapkan adanya pendapatan lain di luar gaji, mesti harus bekerja di luar jam kerja sebagaimana yang telah ditetapkan. Dengan cara seperti ini pula dapat dihindari adanya pengeluaran uang tanpa sebab bekerja.

Sisi kekurangan penggunaan finger print adalah sering terjadi kesalahan dalam proses identifikasi. Suatu kondisi riil yang sangat mungkin terjadi adalah adanya kesalahan mesin finger print dalam mengimput data sidik jari pegawai. Kondisi ini baru diketahui oleh pegawai yang bersangkutan pada saat adanya pelaporan akhir tahun kinerja (kehadiran) pegawai. Jadi, jika kemudian pegawai tersebut merasa masuk dan juga merasa pulang sesuai dengan aturan, namun mendapatkan laporan bahwa yang bersangkutan dinyatakan tidak masuk, maka hal ini dapat dipastikan akan memunculkan perselisihan (apalagi kalau hasil finger print sudah dilaporkan ditembuskan ke pimpinan yang lebih atas/inspekturat).

\section{AGAMA DAN KEDISIPLINAN KERJA}

Disiplin dilihat dalam pandangan agama Islam, bilamana seseorang bisa bekerja secara disiplin berarti sudah dapat melaksanakan amanah yang telah diberikan oleh orang banyak dengan baik. Dimana seorang yang bekerja secara berorganisasi menghendaki akan perubahan dan mencapai tujuan yang telah direncanakan. Sesuai penjelasan QS Yusuf ayat 11 menyatakan: "sesungguhnya Allah tidak akan merubah apa yang terdapat pada keadaan suatu kaum atau masyarakat, sehingga mereka mengubah apa yang terdapat dalam diri (sikap mental) mereka. Disiplin berasal dari bahasa Latin yaitu diciplina yang memiliki arti latihan atau pendidikan, kesopanan, dan kerohanian yang ada pada diri karyawan terhadap peraturan dan ketetapan perusahaan. Disiplin adalah sikap mental untuk bisa mematuhi peraturan dan bertindak sesuai peraturan secara sukarela. Selain itu ada penjelasan yang al-Qur'an yang lain menyatakan bahwa orang yang dapat menjaga ketaatan dan amanat dari orang banyak berarti sudah bisa bertanggung jawab atas tugas pokoknya.

Kedisiplinan untuk masuk kerja sebenarnya bisa dilakukan dengan cara menanamkan sikap jujur dan amanat dalam bekerja pada setiap diri pegawai. Dengan sikap jujur dan amanah, maka seorang pegawai akan disiplin masuk kerja dan beraktifitas yang baik, sungguh-sungguh, dan maksimal. Mengapa demikian? Sebab, pendisipinan pegawai dengan menggunakan alat finger print semata-mata hanya untuk melakukan pengawasan secara fisik, tetapi pengawasan secara psikis tidak dapat dideteksi. Perilaku jujur adalah selalu berkata dengan benar dan berperilaku sesuai dengan kenyataan atau realitas yang dilihat oleh orang yang mengatakannya, meskipun orang lain tidak mengetahuinya. Dalam QS al-Taubah ayat 119, Allah swt. 
juga meminta kaum beriman untuk bergabung bersama orang-orang yang benar dan jujur, yaitu: "Wahai orang-orang yang beriman! Bertakwalah kepada Allah, dan bersamalah kamu dengan orang-orang yang benar."

Selain jujur, menepati janji juga merupakan pendidikan mental kepribadian pada diri pegawai. Jika pada diri setiap pegawai tertanam sikap amanah, maka dia akan melakukan apa yang wajib bagi dirinya untuk dilakukan, baik itu janji tertulis secara resmi maupun berupa ucapan atau bukan merupakan sesuatu yang disepakati. Orang-orang yang yang menghiasi dirinya dengan sifat selalu menepati janji, maka termasuk orang yang akan menempati kedudukan sebagai orang-orang yang berakal, cerdas dan bijaksana, seperti yang dijelaskan oleh Allah swt. dalam QS al-Ra'du ayat 19-20: "Hanya orang yang berakal saja yang dapat mengambil pelajaran, (yaitu) orang yang memenuhi janji Allah dan tidak melanggar perjanjian." Bahkan, Allah swt. menjadikan sifat menepati janji sebagai salah satu medium yang bisa digunakan oleh para hamba yang selalu menepati janji untuk meraih apa yang telah dijanjikan-Nya kepada mereka. Selanjutnya Allah swt. berfirman dalam QS al-Baqarah ayat 40: “Dan penuhilah janjimu kepada-Ku, niscaya Aku penuhi janji-Ku kepadamu, dan takutlah kepada-Ku saja.” Bahkan, Allah swt. juga berfirman dalam QS al-Isrā' ayat 34: “...dan penuhilah janji, karena janji itu pasti diminta petanggungjawabannya."

\section{PENUTUP}

Kedisiplinan sebagai sebuah sikap yang dituntut secara tidak langsung oleh lembaga atau organisasi, seharusnya dimiliki oleh setiap orang yang terbangun dalam sebuah lembaga atau organisasi. Kedisiplinan pada diri seseorang akan muncul dengan sendirinya apabila pada diri seseorang tersebut tertanam sikap jujur dan amanah serta bertanggung jawab. Jika seseorang telah memiliki sikap jujur dan amanah, maka kinerja tidak terpengaruh oleh penggunaan finger print. Mengapa demikian, sebab sebaik apapun alat yang dipakai untuk mengawasi orang dalam bekerja (termasuk finger print), maka alat itupun masih sangat mungkin diubah atau direkayasa (misalnya melalui operator input data sidik jari) untuk dibuat bahwa pegawai yang dimaksud telah benar-benar masuk.

\section{CATATAN AKHIR:}

1. Lihat Suharsimi Arikunto, Manajemen Pengajaran, Jakarta: PT Rineka Cipta, 1993, h. 122123.

2. Lihat ibid.

3. Ngainun Naim, Character Building, Jogjakarta: Ar-Ruzz Media, 2012, h. 143.

4. Barnawi dan Mohammad Arifin, Instrumen Pembinaan, Peningkatan, dan Penilaian Kinerja Guru Profesional. Jogjakarta: Ar-Ruzz Media, 2012, h. 110.

5. Ondi Saondi dan Aris Suherman, Etika Profesi Keguruan, Bandung: PT Refika Aditama, 2010, h. 40.

6. Abdurrahmat Fathoni, Organisasi dan Manajemen Sumber Daya Manusia, Jakarta: PT Rineka Cipta, 2006, 126. 
7. Ondi Saondi dan Aris Suherman, Etika Profesi Keguruan, Bandung: PT Refika Aditama, 2010, h. 41.

8. Barnawi dan Mohammad Arifin, Instrumen Pembinaan, Peningkatan, dan Penilaian Kinerja Guru Profesional, Jogjakarta: Ar-Ruzz Media, 2012, h. 115.

9. Lihat Henry Simamora, Manajemen Sumber Daya Manusia, Yogyakarta: STIE, 1997, h. 116.

10. Lihat Tulus Tu'u, Peran Disiplin pada Perilaku dan Prestasi Siswa, Jakarta: Grasindo, 2004, h. 64.

11. Lihat Oteng Sutrisno dalam Barnawi dan Mohammad Arifin, Instrumen Pembinaan, Peningkatan, dan Penilaian Kinerja Guru Profesional, Yogyakarta: Ar-Ruzz Media, 2012, h. 113.

\section{DAFTAR PUSTAKA:}

Fathoni, Abdurrahmat. Organisasi dan Manajemen Sumber Daya Manusia. Jakarta: PT Rineka Cipta, 2006.

Saondi, Ondi dan Aris Suherman. Etika Profesi Keguruan. Bandung: PT Refika Aditama, 2010.

Tu'u, Tulus. Peran Disiplin pada Perilaku dan Prestasi Siswa. Jakarta: Grasindo, 2004.

Sutrisno, Oteng dalam Barnawi dan Mohammad Arifin. Instrumen Pembinaan, Peningkatan, dan Penilaian Kinerja Guru Profesional, Yogyakarta: Ar-Ruzz Media, 2012.

Barnawi dan Mohammad Arifin. Instrumen Pembinaan, Peningkatan, dan Penilaian Kinerja Guru Profesional. Jogjakarta: Ar-Ruzz Media, 2012.

Arikunto, Suharsimi. Manajemen Pengajaran. Jakarta: PT Rineka Cipta, 1993.

Rahman, Masykur Arif. Kesalahan-kesalahan Fatal Paling Sering Dilakukan Guru dalam Kegiatan Belajar Mengajar. Yogyakarta: DIVA Press, 2012.

Ngainun, Naim. Character Building. Jogjakarta: Ar-Ruzz Media, 2012.

Saondi, Ondi dan Aris Suherman. Etika Profesi Keguruan. Bandung: PT Refika Aditama, 2010.

Simamora, Henry. Manajemen Sumber Daya Manusia. Yogyakarta: STIE, 1997.

http:// filmpelajar.com/blog/upaya-meningkatkan-kedisiplinan-guru-melalui keteladanankepala-sekolah.

http://hargafingerprintreader.blogspot.co.id/2016/02/kelebihan-dan-kekurangan-mesinabsen.html 